\title{
Long-distance transport of macromolecules through the phloem
} Julia Kehr

\author{
Address: Centro de Biotecnología y Genómica de Plantas (UPM-INIA), Campus de Montegancedo, Autopista M40 (km 38), \\ 28223 Pozuelo de Alarcón, Madrid, Spain \\ Email: julia.kehr@upm.es
}

FI000 Biology Reports 2009, I:3I (doi:I0.34I0/BI-3I)

The electronic version of this article is the complete one and can be found at: http://FI000.com/Reports/Biology/content/I/3 I

\begin{abstract}
Long-distance phloem transport of small metabolites has long been the subject of many different studies concentrating on resource allocation and signalling between plant organs. Also, phloem movement of viruses has long been examined as the route for systemic infection of the plant. Only recently, the transport of macromolecules, such as proteins and nucleic acids, has received increasing attention because they are regarded as being a new class of potential information-transmitter. A set of recent publications allows the first insights into the important roles that phloem-mobile macromolecules might play in the regulation of development and the responses to stress. Furthermore, they start to shed light on the mechanisms involved in systemic macromolecule transport.
\end{abstract}

\section{Introduction and context}

Cell-to-cell and interorgan exchange of nutrients and information is essential for growth, development, successful reproduction, and environmental adaptation of multicellular organisms. Higher land plants have evolved a plant-specific symplastic network connected via plasmodesmata (PD), cytoplasmic connections between plant cells, which allow a locally restricted exchange of information. In addition, a rapid transfer of information over longer distances is enabled by the phloem. PD and the phloem thus provide a continuous symplastic connection between even the most distant plant organs.

The phloem of higher land plants is a channel system mainly responsible for the allocation of organic nutrients that are produced during photosynthesis (photoassimilates) from 'source' organs (those with a net production of photoassimilates, such as green leaves) to 'sink' organs (those with a net consumption, such as roots or fruits). Together with the xylem (dead tubes that transport water from root to shoot), the phloem is located in vascular bundles. The transport tubes of the phloem, the so-called sieve elements (SEs), are living but partially degenerated cells that lose important cellular components such as vacuoles, the nucleus, or ribosomes during maturation. As a consequence, SEs have presumably lost the capacity for transcription and translation, resulting in their inability to synthesise RNAs or proteins. The specific maturation and their interconnection with other adjacent SEs make these tubes suited for efficient and quick substance transport, but hardly viable. For survival, SEs are therefore always intimately associated with their neighbouring companion cells (CCs), and both emerge from the division of a single mother cell. CCs remain fully equipped and develop high metabolic activity in order to provide SEs with all the vitally important compounds. To allow a steady transfer of molecules of different molecular classes and sizes, CCs and SEs are connected by special PD, namely the pore plasmodesmal units, which are formed by multiple channels on the CC side that lead into a single pore on the SE side. As a result, the size of molecules allowed to pass these PD, the so-called size exclusion limit (SEL), is quite high $(>67$ $\mathrm{kDa})$ as compared with that of other PD (1 kDa) [1]. In addition, the capacity of many phloem polypeptide compounds to further increase the SEL [2] should, in principle, also enable macromolecules to pass through. It 
is well known that many plant viruses (macromolecular structures consisting of nucleic acids and proteins) exploit this symplastic pathway to spread from cell to cell and systemically through the entire plant. It was only recently discovered that a high number of plant endogenous macromolecules, such as proteins and RNAs, are also present within the phloem, which suggested that they might act as information-transmitting molecules in a diverse range of physiological processes. However, only recent advances have confirmed that some of these endogenous macromolecules can indeed be transported in living plants to influence developmental processes, as well as stress and defence responses. In addition, advances mainly from plant virus research allow new insights into the mechanisms that underlie the systemic translocation of macromolecules.

\section{Major recent advances}

\section{Phloem transport of viruses}

Long-distance transport of macromolecules was first seen by observing the spread of viruses that misuse the phloem for their passive translocation through the plant, leading to the spread of the infection, especially into growing areas. After infection, viruses normally spread locally from cell to cell through PD until they reach the phloem. Viruses contain special proteins, namely movement proteins (MPs), that can bind and unfold single-stranded RNAs and facilitate their intercellular translocation by building protein-RNA transport complexes [ribonucleoprotein (RNP) complexes] [3]. It is currently unknown whether MPs are also needed for phloem-dependent movement [4]. However, several studies indicate that cell-to-cell and systemic virus transport follow different mechanisms [5-7], and there seem to be different viral and endogenous plant components involved [7-10]. In addition to MP, an important viral factor for phloem movement is the coat protein that seems to be strictly required for long-distance translocation of several groups of viruses $[11,12]$.

With regard to endogenous plant factors, a cell wall glycine-rich protein and a pectin methylesterase have been shown to influence viral spread, probably by modulating the permeability of PD $[5,7,13]$. An interesting recent finding is that the interaction of the groundnut rosette virus ORF3 protein with subnuclear Cajal bodies and the nucleolus is required to capture the plant protein fibrillarin to form an RNP complex capable of long-distance phloem movement [14,15]. Also, endogenous phloem proteins, namely different phloem lectins and the phloem protein CmPP16 (a protein with properties resembling those of virus MPs), have been found to interact with viral RNAs and endogenous mRNAs and thus have been suggested to be involved in virus import and/or translocation as RNP complexes $[16,17]$, but a conclusive demonstration of their importance for viral spread is, as yet, missing.

\section{Phloem transport of endogenous macromolecules}

The occurrence of unspecified RNA species was described nearly 40 years ago, but it was long regarded as an artefact caused by sampling. The first evidence that endogenous plant mRNAs are present in SEs came from the in situ localisation of the mRNA of a sucrose transporter in SEs and the PD connecting SEs to CCs [18]. Meanwhile, a range of different mRNAs from phloem samples of various species, obtained using different sampling techniques, have been detected (reviewed in [19]) and they are nowadays regarded as being authentic components of the phloem stream. At the same time, heterografting studies performed by different research groups could show that specific transcripts can indeed move and, moreover, induce phenotypic alterations in their target tissues [20-22]. For example, in potato, overexpression of the transcription factor BEL1 mRNA induced a marked increase of tubers per plant, and this phenomenon could cross graft junctions, thus indicating phloem mobility of this mRNA [23].

Recently, small RNAs of fewer than 30 nucleotides [short interfering RNAs (siRNAs) and microRNAs (miRNAs)] were found to occur in the phloem stream [24-26]. siRNAs are involved in a process called post-transcriptional gene silencing, an innate plant defence mechanism against transposable elements and viruses [27] that can spread systemically throughout the plant [28]. While siRNAs are generally assumed to be mobile between cells and also systemic [29], most miRNAs, involved mainly in controlling developmental processes, seem to act cellautonomously under normal growth conditions in adult tissues, as demonstrated, for example, by miR171 $[30,31]$. However, it was recently shown that specific nutrient starvation-responsive miRNAs (such as miR395 that responds to sulphur, miR398 to copper, and miR399 to phosphate stress) can accumulate in the phloem at high levels when plants are grown under the respective nutrient-deprived condition [26]. Moreover, different results suggested that during phosphate deprivation systemic signalling is required [32,33], and recently miR399 was shown to be indeed translocated across graft junctions in the model species Arabidopsis, indicating that phloem movement of this specific miRNA could be involved in regulating the response toward phosphate starvation systemically [34,35]. This observation, however, does not answer the question of whether miRNAs are generally mobile or immobile from cell to cell and over long distances. There might exist a 
small subset of specific mobile miRNAs, or miRNA mobility might be restricted to particular developmental stages and/or specific environmental conditions.

Also, the occurrence of proteins in phloem sap was noticed a long time ago and since then different studies that comprehensively identified phloem proteins from various species have been published [36-38]. However, the capability of the polypeptides to be transported in vivo has been demonstrated for only a few of them (for example, the pumpkin phloem protein CmPP16 that, as mentioned above, displays similarities to viral MPs) [39]. Moreover, the physiological functions of most of the phloem polypeptides remain unknown. For many of them, roles in signal transduction and stress responses have been suggested but not conclusively demonstrated. For several years, the Solanaceae-specific peptide systemin served as the paradigm for a phloem-mobile protein involved in long-distance signalling [40], but according to more recent results, it seems rather likely that it is jasmonic acid and not systemin that constitutes the phloem-translocated signal during wound responses [41]. To date, the only convincing example of a phloem protein involved in signalling is the flower-promoting protein flowering locus $\mathrm{T}$ (FT), which was recently shown to be present in the phloem at detectable concentrations when plants were sampled at the onset of flowering [38]. Subsequently, several independent studies have provided compelling evidence that FT long-distance transport can indeed contribute to flower induction in different plant species [42-46], and the FT protein could thus be a component of the long-sought 'florigen' [47]. Further studies are required to find out whether any of the other phloem sap proteins can act in the information transfer during other developmental processes or stress responses.

Although the transport mechanisms of endogenous macromolecules are not well understood, it is assumed that phloem import and transport of both proteins and RNAs are mediated by specific binding proteins acting as molecular chaperones. It was proposed that phloem heat shock proteins might participate in delivering polypeptides to the phloem $[48,49]$, but other components with functions related to protein folding (for example, the abundant phloem cyclophilins [38]) could also be involved. Several phloem-sap proteins have also been suggested to transport RNAs in the form of RNP complexes since they are RNA-binding, are translocatable across graft unions, and can increase the SEL of PD [17]. In particular, the pumpkin phloem sap protein CmPP16 possesses properties similar to those of viral MPs and mediates the transport of its own and foreign mRNAs from cell to cell and over long distances through the phloem, as shown by microinjection studies and grafting experiments [39]. Small RNA transport in pumpkin seems to follow a similar route mediated by the small RNA-binding phloem protein CmPSRP1 that, however, seems to be restricted to this one plant species [24]. In other plants, one or more of the various RNAbinding phloem proteins that have been described to occur in phloem sap $[16,36,38]$ could possibly do the job. Also, the obvious similarities between the translocation of viruses and endogenous macromolecules suggest that the underlying mechanisms are the same or at least highly similar, but both will need to be demonstrated in future experiments.

\section{Future directions}

The results from recent publications enhance our understanding of why, when, and how viruses and endogenous macromolecules can travel long distances through the phloem. On one hand, they have begun to shed light on the complex mechanisms of the long-observed systemic spread of viruses within plants. On the other hand, they have established that specific endogenous phloem proteins and RNAs can be transported long distances in vivo following certain triggers. While the translocation of viruses clearly serves to spread infection, the transport of endogenous macromolecules might contribute to communicate essential information during developmental processes or stress responses as, for example, for the flower-promoting FT protein or the phosphate-deprivation-induced miR399. Whether this holds true for only a small subset of endogenous macromolecules, or whether there are much more important physiological decisions influenced by the wide range of molecules found in the phloem, requires further investigation. To this end, it will be interesting to comprehensively identify the (sub)set of endogenous macromolecules that can really move long distances in vivo and to analyse the direction of movement and the triggers (developmental and environmental) that initiate transport. It will also be important to identify additional factors and interaction partners required for the movement of different viruses and endogenous macromolecules in order to establish the prerequisites for phloem mobility and import and transport selectivity. This knowledge will be the basis for creating plants with, for example, increased virus or stress resistance, or for influencing important developmental processes by effecting which macromolecules can ride on the 'phloem information highway'.

\section{Abbreviations}

CC, companion cell; FT, flowering locus T; miRNA, microRNA; MP, movement protein; $\mathrm{PD}$, plasmodesmata; 
RNP, ribonucleoprotein; SE, sieve element; SEL, size exclusion limit; siRNA, short interfering RNA.

\section{Competing interests}

The author declares that she has no competing interests.

\section{References}

I. Stadler R, Wright KM, Lauterbach C, Amon G, Gahrtz M, Feuerstein A, Oparka KJ, Sauer N: Expression of GFP-fusions in Arabidopsis companion cells reveals non-specific protein trafficking into sieve elements and identifies a novel postphloem domain in roots. Plant J 2005, 4I:319-31.

FI000 Factor 4.8 Recommended

Evaluated by Walter Kockenberger 24 Jan 2005, John Patrick 17 Mar 2005

2. Balachandran S, Xiang $Y$, Schobert C, Thompson GA, Lucas WJ: Phloem sap proteins from Cucurbita maxima and Ricinus communis have the capacity to traffic cell to cell through plasmodesmata. Proc Natl Acad Sci U S A 1997, 94:|4|50-5.

3. Lucas WJ: Plant viral movement proteins: agents for cell-tocell trafficking of viral genomes. Virology 2006, 344:I69-84.

4. Sareila O, Hohkuri M, Wahlroos T, Susi P: Role of viral movement and coat proteins and RNA in phloem-dependent movement and phloem unloading of tobamoviruses. J Phytopathol 2004, 1 52:622-9.

5. Ghoshroy S, Freedman K, Lartey R, Citovsky V: Inhibition of plant viral systemic infection by non toxic concentrations of cadmium. Plant J 1998, 13:59|-602.

6. Ding XS, Shintaku MH, Carter SA, Nelson RS: Invasion of minor veins of tobacco leaves inoculated with tobacco mosaic virus mutants defective in phloem-dependent movement. Proc Natl Acad Sci U S A 1996, 93: I I 155-60.

7. Ueki S, Citovsky V: The systemic movement of a tobamovirus is inhibited by a cadmium-ion-induced glycine-rich protein. Nat Cell Biol 2002, 4:478-86.

FI000 Factor 3.0 Recommended

Evaluated by Karl Oparka OI Aug 2002

8. Derrick PM, Barker H: Short and long distance spread of potato leafroll luteovirus: effects of host genes and transgenes conferring resistance to virus accumulation in potato. $J$ Gen Virol |997, 78:243-5|.

9. Citovsky V, Ghoshroy S, Tsui F, Klessig D: Non-toxic concentrations of cadmium inhibit systemic movement of turnip vein clearing virus by a salicylic acid-independent mechanism. Plant J 1998, 16:13-20.

10. Gera A, Deom CM, Donson J, Shaw JJ, Lewandowski D, Dawson WO: Tobacco mosaic tobamovirus does not require concomitant synthesis of movement protein during vascular transport. Mol Plant Microbe Interact 1995, 8:784-7.

II. Scholthof HB: Plant virus transport: motions of functional equivalence. Trends Plant Sci 2005, 10:376-82.

12. Callaway AS, George CG, Lommel SA: A sobemovirus coat protein gene complements long-distance movement of a coat protein-null Dianthovirus. Virology 2004, 330: 186-95.

13. Chen MH, Citovsky V: Systemic movement of a tobamovirus requires host cell pectin methylesterase. Plant J 2003, 35:386-92.

FI000 Factor 3.0 Recommended

Evaluated by Julia Kehr 22 Aug 2003

14. Kim SH, Ryabov EV, Kalinina NO, Rakitina DV, Gillespie T, MacFarlane S, Haupt S, Brown JWS, Taliansky M: Cajal bodies and the nucleolus are required for a plant virus systemic infection. $E M B O$ J 2007, 26:2169-79.

FI000 Factor 6.0 Must Read

Evaluated by Julia Kehr 17 Apr 2007

15. Kim SH, MacFarlane S, Kalinina NO, Rakitina DV, Ryabov EV, Gillespie T, Haupt S, Brown JWS, Taliansky M: Interaction between a plant virus-encoded protein and the major nucleolar protein, fibrillarin, is required for virus systemic infection. Proc Natl Acad Sci U S A 2007, I 04: I I I I5-20.

FI000 Factor 3.0 Recommended

Evaluated by Andy Maule 25 Jun 2007

16. Gomez G, Pallas V: A long-distance translocatable phloem protein from cucumber forms a ribonucleoprotein complex in vivo with Hop stunt viroid RNA. J Virol 2004, 78:10104-10.

FI000 Factor 3.0 Recommended

Evaluated by Andy Maule 06 Oct 2004

17. Gomez G, Torres H, Pallas V: Identification of translocatable RNA-binding phloem proteins from melon, potential components of the long-distance RNA transport system. Plant J 2005, 4I:107-16

18. Kühn C, Franceschi VR, Alexander Schulz, Lemoine R, Frommer WB: Macromolecular trafficking indicated by localization and turnover of sucrose transporters in enucleate sieve elements. Science 1997, 275:1298-300.

19. Kehr J, Buhtz A: Long distance transport and movement of RNA through the phloem. J Exp Bot 2008, 59:85-92.

20. Ruiz-Medrano R, Xoconostle-Cázares B, Lucas WJ: Phloem longdistance transport of CmNACP mRNA: implications for supracellular regulation in plants. Development 1999 , 126:4405-19.

21. Kim M, Canio W, Kessler S, Sinha N: Developmental changes due to long-distance movement of a homeobox fusion transcript in tomato. Science 2001, 293:287-9.

FI000 Factor 8.2 Exceptional

Evaluated by Robert Sablowski 06 Sep 200I, Detlef Weigel 16 Oct 200I, Elizabeth Kellogg 20 Nov 2001

22. Haywood V, Yu TS, Huang NC, Lucas WJ: Phloem long-distance trafficking of GIBBERELLIC ACID-INSENSITIVE RNA regulates leaf development. Plant J 2005, 42:49-68.

FI000 Factor 3.0 Recommended Evaluated by Seth J Davis II Apr 2005

23. Banerjee AK, Chatterjee M, Yu Y, Suh SG, Miller WA, Hannapel DJ: Dynamics of a mobile RNA of potato involved in a longdistance signaling pathway. Plant Cell 2006, I 8:3443-57.

24. Yoo BC, Kragler F, Varkonyi-Gasic E, Haywood V, Archer-Evans S, Lee YM, Lough TJ, Lucas W]: A systemic small RNA signaling system in plants. Plant Cell 2004, 16:1979-2000.

FI000 Factor 4.8 Must Read

Evaluated by Elizabeth Kellogg 24 Aug 2004, Daniel Gallie 26 Aug 2004

25. Atkins CA, Smith PM: Translocation in legumes: assimilates, nutrients, and signaling molecules. Plant Physiol 2007, |44:550-6I.

26. Buhtz A, Springer F, Chappell L, Baulcombe DC, Kehr J: Identification and characterization of small RNAs from the phloem of Brassica napus. Plant J 2008, 53:739-49.

FI000 Factor 3.0 Recommended Evaluated by Andy Maule 05 Mar 2008

27. Waterhouse PM, Wang MB, Lough $\mathrm{T}$ : Gene silencing as an adaptive defence against viruses. Nature 200 I, 4I I:834-42.

28. Voinnet $O$, Baulcombe DC: Systemic signalling in gene silencing. Nature 1997, 389:553. 
29. Himber C, Dunoyer P, Moissiard G, Ritzenthaler C, Voinnet O: Transitivity-dependent and -independent cell-to-cell movement of RNA silencing. EMBO J 2003, 22:4523-33.

FI000 Factor 6.5 Must Read

Evaluated by Andy Maule OI Sep 2003, Julia Kehr 16 Sep 2003, Detlef Weigel 22 Sep 2003

30. Parizotto EA, Dunoyer P, Rahm N, Himber C, Voinnet O: In vivo investigation of the transcription, processing, endonucleolytic activity, and functional relevance of the spatial distribution of a plant miRNA. Genes Dev 2004, I 8:2237-42.

FI000 Factor 6.0 Must Read

Evaluated by Andy Maule 06 Oct 2004

31. Voinnet O: Non-cell autonomous RNA silencing. FEBS Lett 2005, 579:5858-7I.

32. Liu J, Samac DA, Bucciarelli B, Allan DL, Vance CP: Signaling of phosphorus deficiency-induced gene expression in white lupin requires sugar and phloem transport. Plant J 2005, 4 I:257-68.

FI000 Factor 3.0 Recommended

Evaluated by Julia Kehr 31 Jan 2005

33. Bari R, Pant BD, Stitt M, Scheible WR: PHO2, microRNA399, and PHRI define a phosphate-signaling pathway in plants. Plant Physiol 2006, 141:988-99.

34. Pant BD, Buhtz A, Kehr J, Scheible WR: MicroRNA399 is a longdistance signal for the regulation of plant phosphate homeostasis. Plant J 2008, 53:731-8.

FI000 Factor 4.8 Recommended

Evaluated by Brian Forde 20 Nov 2007, Susan Barker 25 Feb 2008

35. Lin SI, Chiang SF, Lin WY, Chen JW, Tseng CY, Wu PC, Chiou TJ: Regulatory network of microRNA399 and PHO2 by systemic signaling. Plant Physiol 2008, I47:732.

FI000 Factor 6.0 Must Read

Evaluated by David Jackson 07 Oct 2008

36. Barnes A, Bale J, Constantinidou C, Ashton P, Jones A, Pritchard J: Determining protein identity from sieve element sap in Ricinus communis L. by quadrupole time of flight (Q-TOF) mass spectrometry. J Exp Bot 2004, 55:|473-8I.

37. Walz C, Giavalisco P, Schad M, Juenger M, Klose J, Kehr J: Proteomics of curcurbit phloem exudate reveals a network of defence proteins. Phytochemistry 2004, 65:1795-804.

38. Giavalisco P, Kapitza K, Kolasa A, Buhtz A, Kehr J: Towards the proteome of Brassica napus phloem sap. Proteomics 2006, 6:896-909.

39. Xoconostle-Cázares B, Xiang Y, Ruiz-Medrano R, Wang HL, Monzer J, Yoo BC, McFarland KC, Franceschi VR, Lucas WJ: Plant paralog to viral movement protein that potentiates transport of mRNA into the phloem. Science 1999, 283:94-8.
40. Narvaez-Vasquez J, Pearce G, Orozco-Cardenas ML, Franceschi VR, Ryan CA: Autoradiographic and biochemical evidence for the systemic translocation of systemin in tomato plants. Planta 1995, 195:593-600.

4I. Li L, Li C, Lee GI, Howe GA: Distinct roles for jasmonate synthesis and action in the systemic wound response of tomato. Proc Natl Acad Sci U S A 2002, 99:64I6-2I.

FI000 Factor 9.0 Exceptional

Evaluated by John Browse 13 May 2002

42. Corbesier L, Vincent C, Jang S, Fornara F, Fan Q, Searle I, Giakountis A, Farrona S, Gissot L, Turnbull C, Coupland G: FT Protein movement contributes to long-distance signaling in floral induction of Arabidopsis. Science 2007, 3 I 6:1030-3.

FI000 Factor 3.0 Recommended

Evaluated by Daniel Gallie I 3 Jun 2007

43. Mathieu J, Warthmann N, Kuttner F, Schmid M: Export of FT protein from phloem companion cells is sufficient for floral induction in Arabidopsis. Curr Biol 2007, I 7:1055-60.

FI000 Factor 3.0 Recommended

Evaluated by Julin Maloof 27 Jul 2007

44. Lin MK, Belanger H, Lee YJ, Varkonyi-Gasic E, Taoka KI, Miura E, Xoconostle-Cázares B, Gendler K, Jorgensen RA, Phinney B, Lough TJ, Lucas WJ: FLOWERING LOCUS T protein may act as the long-distance florigenic signal in the cucurbits. Plant Cell 2007, 19:|488-506.

45. Jaeger KE, Wigge PA: FT protein acts as a long-range signal in Arabidopsis. Curr Biol 2007, 17:1050-4.

FI000 Factor 3.0 Recommended Evaluated by Julia Kehr 08 Jun 2007

46. Tamaki S, Matsuo S, Wong HL, Yokoi S, Shimamoto K: Hd3a protein is a mobile flowering signal in rice. Science 2007, 3 I 6: I033-6.

FI000 Factor 3.0 Recommended

Evaluated by Daniel Gallie 13 Jun 2007

47. Chailakhyan MK: New facts in support of the hormonal theory of plant development. Comptes Rendus (Doklady) de l'Academie des Sciences des l'URSS 1936, 13:79-83.

48. Aoki K, Kragler F, Xoconostle-Cázares B, Lucas WJ: A subclass of plant heat shock cognate 70 chaperones carries a motif that facilitates trafficking through plasmodesmata. Proc Natl Acad Sci U S A 2002, 99:16342-7.

FI000 Factor 3.0 Recommended Evaluated by Julia Kehr 09 Dec 2002

49. Lough TJ, Lucas WJ: Integrative plant biology: role of phloem long-distance macromolecular trafficking. Ann Rev Plant Biol 2006, 57:203-32. 